\title{
DE
} DE GRUYTER OPEN

Arch. Min. Sci., Vol. 61 (2016), No 4, p. 875-892

Electronic version (in color) of this paper is available: http://mining.archives.pl

DOI 10.1515/amsc-2016-0058

PIOTR KRAWCZYK*1 , MARZENA MAJER*, JOANNA KRZEMIEN'*

\section{PROPOSAL OF ECONOMIC ASSESSMENT OF HARD COAL MINES OPERATION CONDUCTED IN POLISH CONDITIONS WITH THE USE OF COST BENEFIT ANALYSIS}

\section{PROPOZYCJA OCENY EKONOMICZNEJ FUNKCJONOWANIA KOPALNI WĘGLA KAMIENNEGO W WARUNKACH POLSKICH Z WYKORZYSTANIEM METODYKI ANALIZ KOSZTÓW I KORZYŚCI}

\begin{abstract}
The paper presents possibilities of an economic evaluation of hard coal mines, using Cost Benefit Analysis (CBA). Suggested methodology for CBA applied to the economic evaluation of a mine allows to conduct a complex evaluation of mine's functionality in connection to Polish conditions. Additionally to financial aspects, significant from the point of view of the mine's owner, the paper includes social and environmental effects as a result of mining activities. Proposed methodology has undergone tests which used averaged data obtained from two selected hard coal mines located in the Upper Silesian Coal Basin. Presented results confirm the validity of social costs and benefits, and environmental losses resulting from mining operation, which were included in analysis comprehensively evaluating the efficiency of hard coal mines.
\end{abstract}

Keywords: Cost Benefit Analysis, CBA, hard coal mine, economic efficiency

W pracy przedstawiono możliwości zastosowania oceny ekonomicznej kopalni węgla kamiennego z wykorzystaniem metodyki analiz kosztów i korzyści (Cost Benefit Analysis - analiza CBA). Zaproponowano metodykę zastosowania analizy CBA do oceny ekonomicznej kopalni, która umożliwia kompleksową ocenę jej funkcjonowania w warunkach polskich. Oprócz aspektów finansowych istotnych z punktu widzenia właściciela kopalni, ujęto również oddziaływania społeczne i środowiskowe wynikające $\mathrm{z}$ wpływu kopalni na otoczenie. Zaproponowaną metodykę przetestowano z wykorzystaniem uśrednionych danych $\mathrm{z}$ dwóch wybranych kopalń węgla kamiennego zlokalizowanych na terenie Górnośląskiego Zagłębia Węglowego. Przedstawione wyniki potwierdzają zasadność uwzględniania kosztów i korzyści społecznych oraz strat środowiskowych wynikających z działalności górniczej w analizach oceniających kompleksowo efektywność funkcjonowania kopalń węgla kamiennego.

Słowa kluczowe: analiza kosztów i korzyści CBA, kopalnia węgla kamiennego, efektywność ekonomiczna

* CENTRAL Mining INSTITUTE, PLAC GWARKÓW 1, 40-166, KATOWICE, POLAND

CORRESPONDING AUTHORS: E-mail: pkrawczyk@gig.katowice.pl 


\section{Introduction}

Mining operation in coal mines is a complex process consisting of several interrelated subprocesses, which directly or indirectly affect the environment. The effects of these actions can be both, negative, known as loss (e.g. environmental) or positive, for instance in the form of social benefits. Including only traditional financial analysis of mine operation as a company in the evaluation is not sufficient, as it involves only a narrow range of financial aspects directly related to the production and sale of coal. Such analysis allows to evaluate only financial sustainability and efficiency of a company - the mine. The full image of mine operation can be provided by an economic evaluation performed using CBA methodology which applies economic values reflecting the costs of an alternative usage of the resources by the mine, or the price that the society is ready to pay for a particular good or service. The CBA takes into account and values all factors according to their alternative cost for the society (Ligus, 2010).

The economic analysis performed on the basis of CBA is related to the principle that includes prices based on the alternative cost of a given resource and reflecting macroeconomic efficiency investments, unlike financial analysis, which is based on a system of market prices. The analysis with applied CBA enables to conduct an evaluation whether a project should be supported from the perspective of general society (Henzej et al., 2000). CBA is in fact aimed at an evaluation of project's contribution to economic growth and welfare of a region or country. Such analysis is carried out in reference to the benefits of the whole society (of a particular region or country), contrary to the financial analysis which adopts the perspective of an investor (Florio et al., 2001).

CBA extends financial evaluation by taking into account the so-called external factors: the benefits to society arising from the operation of the mine, as well as losses resulting from the negative impact on the surrounding environment. Valuation of environmental costs and human life and health creates many difficulties as external effects (social costs and benefits, and environmental costs) are not cash expenditure. If the benefits and costs cannot be measured in monetary terms, the principle of indirect valuation of these elements is applied.

The article presents an overview of works devoted to the estimation of losses and benefits associated with mining activities, characteristics and complexity of the processes associated with the production of coal, the methodology for CBA, and the results of test calculations of the proposed methodology for the economic evaluate of the coal mine. Tested CBA of a mine has been carried out on the basis of actual averaged operating and financial data from two Polish mines.

\section{Knowledge base in the field of the application of Cost Benefit Analysis methodology to the evaluation of mines in Poland}

Research aimed at determining ecological losses and socio-economic benefits resulting from mining activities began in Poland in the 80s. A research team led by Franciszek Piontek estimated the losses caused by the degradation of land surface in Katowice province (Piontek, 1989), and determined detailed socio-economic costs of coal mining (1992). These works did not include the whole country, but thoroughly depicted estimated balance of ecological losses and social benefits carried out for mines located in the former province of Katowice. In 1992 Mokrzycki et al. presented the impacts of air, water and soil pollution on the natural environ- 
ment, and included other methods for estimation losses in the environment, human health and buildings. Presented results were obtained as a part of the project "Increasing the efficiency of the extraction and use of mineral resources “. Famielec (1999) described in his work a methodology for evaluating economic losses caused by environmental pollution in domestic economy. Next works, presented by Martyka, Nowak and Tausz (2001), included the way how society viewed activities of the mines, the consequences posed by mining activities, and hence the need to take into account the economic streams in the balance of costs and benefits generated by the mine.

The technique of environmental evaluation - LCA (Life Cycle Assessment), was developed in subsequent years. LCA is often combined with costs analysis - LCC (Life Cycle Costing) (Czaplicka-Kolarz, 2002; Kulczycka, 2011). The results of LCA and LCC may serve as the basis for an analysis of costs and benefits, as shown by Kulczycka, Koneczny and Kowalski (2003). The Central Mining Institute carried out cost analysis (LCC), environmental analysis (LCA) and eco-efficiency analysis for coal gasification technology (Burchart-Korol et al., 2013). The analysis were conducted as a part of "Development of coal gasification technology for high fuel and energy production" project. Performed eco-efficiency analysis allows to select the variant which would provide the greatest benefits at the lowest cost, while obtaining the least burden to the natural environment (so-called eco-efficient solutions) (Czaplicka-Kolarz \& Ściążko, 2004).

Polish specialist literature fairly extensively includes works on the use of Cost Benefit Analysis to assess the management of mining waste. Kulczycka, Uberman and Naworyta (2012) depicted in their work the economic and non-economic benefits resulting from the use of both, associated minerals and mining waste in the brown coal mining. Additionally, they presented evaluation methods for economic viability of development of minerals associated with mining works. Kulczycka, Uberman and Cholewa (2012) suggested that Cost Benefit Analysis should be included to the assessment of mining waste management. Other publication on CBA was presented as a part of Min-Novation project and was based on an analysis of possible methods to develop mining waste in the Baltic region, and depicted economic and non-economic benefits of this process (Cała, 2013).

In terms of cost estimation of accidents at work and occupational diseases, activities carried out by the European Agency for Safety and Health at Work are significant. Possible methods for estimating these costs on the national scale was developed in the Central Institute for Labour Protection (PIB) and the Nofer Institute of Occupational Medicine in Łódź.

The problem whether to include environmental and social effects of the valuation of degraded areas in terms of multi-criteria method was presented by Janik (2012). The author highlights the fact that the methods of valuation of land located in degraded areas do not include consequent environmental and social costs losses. This is significant due to the fact that the share of coal and energy mining resources in the total area of degraded land in Poland amounts to $20.6 \%$. The negative impact of mines on the surface does not involve only issue of mining damage, but also causes decline of aesthetic qualities of the area. The estimation of such costs of mining operation is not developed sufficiently. Expanded approach to the valuation of external costs of infrastructure projects - HEATCO, IMPACT, or guidelines created for the needs of EU- DG Mobility and Transport, can become a good practice and a reference point for further work in this area.

The analysis of knowledge on the valuation of benefits and costs related to mining should also include Code for the Valuation of Mineral Assets developed by the Polish Association of Mineral Assets Valuation and, the work dedicated to the subject of valuation of mineral assets (www.polval.pl and Uberman, 2009). 
Development of CBA became a necessity when an entity or a party applies for financial support of infrastructure projects from EU funds. A guide for entities seeking financial support of the European Union, released under the authority of the European Commission, is a response to the need of CBA. The analysis includes additional aspects of industry impacts, so-called external effects (improvement or deterioration of environmental quality, increase or reduction of employment or cultural heritage protection). The aspects were introduced in order to help to select the most profitable projects, which do not need financial support from public funds. Ultimately, the EU funds are designed to subsidize projects unprofitable for investors, but valuable from a socioeconomic point of view (European Commission, Directorate General Regional Policy, 2008). The results of European Union guidelines are visible in the case of investment applications, as well as in the program reports of state administration bodies. Examples of other applications of CBA in large investment projects in the world were presented by Gillespie and Krat (2010), and Gillespie Economics (2011).

The estimate of external costs caused by energy technologies using traditional energy sources was presented in the work elaborated by Kudełko (2013). The author (2005) using a model based approach estimated the external costs arising from the activities of a plant producing rock resources.

Despite a visible growing importance of CBA and its scope, this methodology has not been applied to the needs of a comprehensive assessment of mining activities in Poland.

\section{Characteristics of the adopted model of hard coal mine}

The economic evaluation of mining operations, which includes CBA, requires taking into account specific nature of the industry. The coal production is extremely complex and based on a complicated system of interrelated processes. In this case, certain aspects are significant and essential, such as knowledge of principles and basic processes on which this type of business is based under national conditions, and also relatively detailed description of the processes and their interdependencies (Dubiński, 2013). Only having this information, it is possible to conduct full analysis of the model of coal mine in terms of its specifics of conducting economic evaluations using CBA which includes a broader perspective of assessment rather than financial analysis (Dubiński \& Turek, 2014).

The model of coal mine should take into account the current structure of the production process. The structure of the coal production process is understood as "a system of partial processes, activities, and technological operations, carried out at a specific time, place and space, which are performed by teams of men, using specific technical means and are designed to produce salable coal with appropriate qualitative parameters "(Burchart-Korol et al., 2014).

The overall structure of the coal production process according to the above definition is illustrated in Figure 1.

The determined coal production structure focuses on the partial processes defined as „the processes which implementation is essential from the point of view of coal production“ (Burchart-Korol et al., 2014). Four main groups of partial processes: preparatory, basic, auxiliary and the accompanying, were determined in relation to the mine. Proper analysis of the processes related to the production of coal cannot be limited to a definition of their overall structure. It 


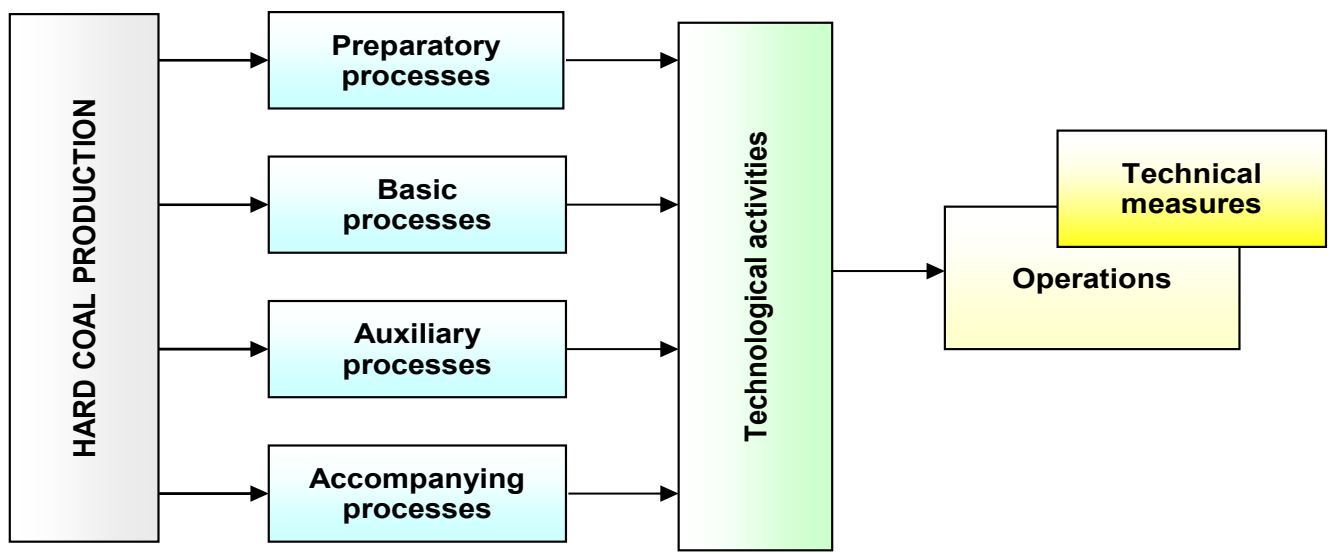

Fig. 1. The general structure of coal production process (Turek, 2013)

is significant to identify unit processes, which are a part of major groups of sub-processes, in order to properly understand the process of coal production and the complexity of the operation of the mine (Czaplicka-Kolarz et al., 2015). Summary of unit processes carried out in the mine is shown in Figure 2.

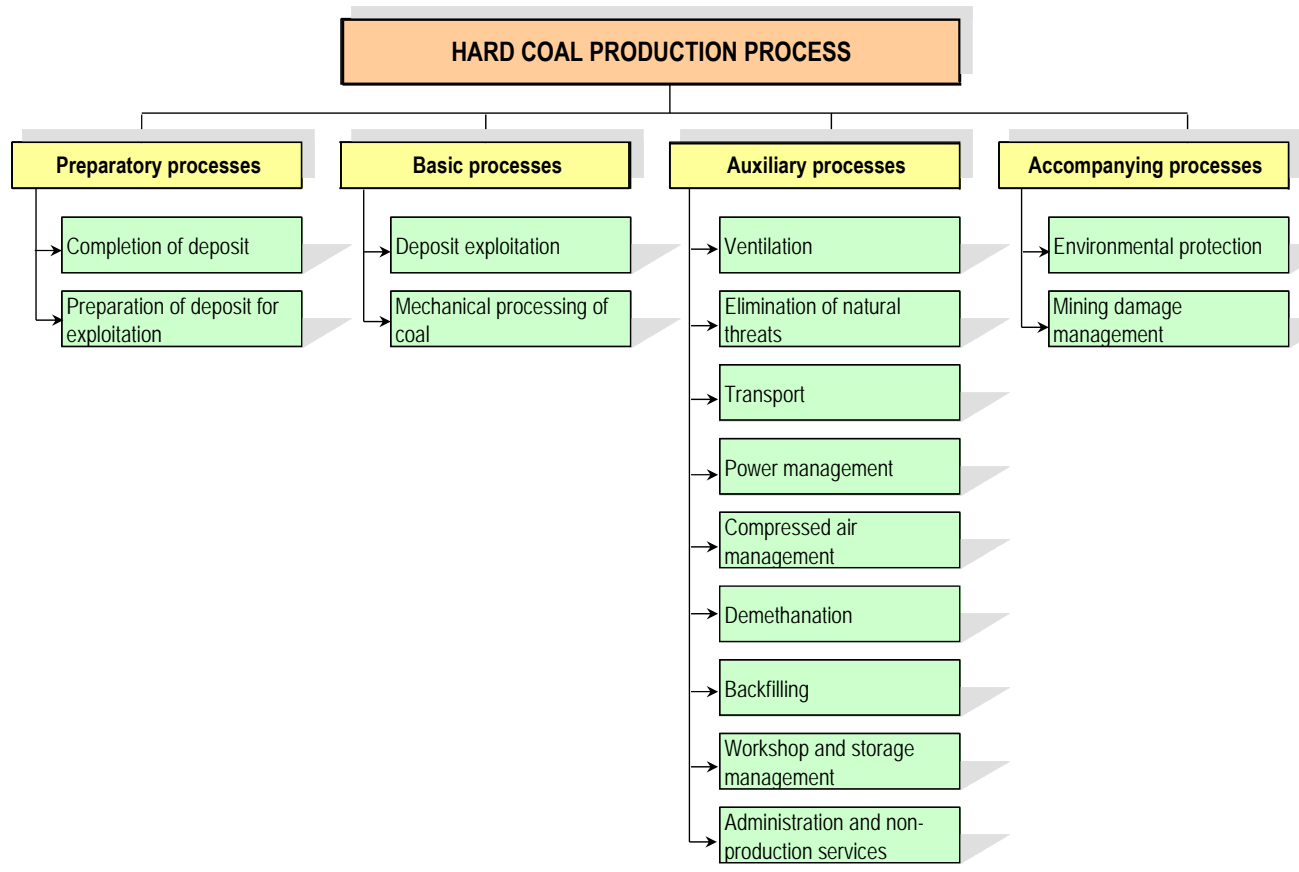

Fig. 2. The structure of unit and partial processes of coal mine (Turek, 2013) 
The diagram of unit processes and groups of partial processes shown in Figure 2 demonstrates the extreme complexity of the mine's model. The lack of a simple sequence in the order of the individual unit processes is particularly important in the context of CBA. This applies particularly to processes included in the two groups of partial processes, namely associated and auxiliary processes. Their implementation is applied in different sequences and overlaps with basic and preparatory processes. Considering the broader perspective of CBA, and need to include external social and environmental effects, it is reasonable to conduct cost-benefit analysis in relation to the overall mine model. Lower level of coal production processes in the adopted model of the mine could give rise to errors resulting from the allocation and ,artificial“ link of external effects with the auxiliary and accompanying processes.

\section{Description of adopted methodology for economic evaluation of coal mines with the use of CBA}

Methodology of CBA was development in 1844 by a French economist Jules Dupuit, who dealt with estimating the costs and benefits of public works (Surdej, 2008).

CBA allows to compare and evaluate the full costs and benefits for society and ecosystems associated with specific activities and covering its tangible and intangible costs and benefits. It is used for the economic evaluation of specific projects or strategies, as well as the results of economic activity (Fiedor, 2002). CBA is also used to evaluate and compare the investments and activities which not all major determinants of the level of costs and benefits can be measured by the market (Fiedor, 2002).

The basic element of the analysis is the quantification and valorisation of costs and benefits. Valuable market valuation of elements occurring in the market and constituting costs, as well as products and services designed to be the result of the project, usually do not generate problems. The difficulties are related to the rules of valuation of costs and benefits for the environment, and human life and health. It generally occurs when the external effects (social costs and benefits, and environmental costs) are not cash expenditure. They often relate not only to the expenditure incurred by third parties, but also lost (not achieved) benefits - not only in the current period, but also in future periods, including for future generations. If some benefits and costs cannot be measured in monetary terms, the principle of indirect valuation of these elements could be applied. For instance, when the costs of health deterioration occur in addition to the costs and benefits expressed in value, then the surplus of financial benefits over financial costs (net social surplus) can be compared with the cost of health (non-cash) (Fiedor, 2002).

CBA includes the following stages (Burzyńska, Fila, 2007):

- identification of direct and indirect effects of a given project (positive and negative),

- valuation of identified effects,

- comparison of discounted value of the costs and income associated with the analysed project,

- evaluation of the project's efficiency (calculation of economic indicators of performance).

Moreover, the following aspects are also carried out as a part of CBA (Florio et al., 2001):

- stage 1: correction of effects of taxes, subsidies or other transfers,

- stage 2: correction of external effects,

- stage 3: transformation of market prices to accounting prices, which also allows to take into account the social costs and benefits (determination of conversion factors). 
A significant factor taken into account in CBA are shadow prices. They occur when the market does not work effectively, which means that market prices of resources used in the assessed project do not reflect the value of socio-economic goods (Drobniak, 2002).

When all elements of the analysis can be sufficiently quantified and valorised, then the cost-benefit analysis is to measure Net Present Value (NPV). The updated values of Net Cash Flow from different years of the project life cycle are added to obtain the NPV for the analysed period of the project (Fiedor, 2002). Economic analysis defines this indicator as ENPV - Economic Net Present Value. The letter "E" preceding the determination of this ratio indicates that it relates to economic analysis and that it is based on shadow prices, as opposed to NPV which is based only on cash flow (Kawala et al., 2002; Florio et al., 2001, Drobniak, 2002). The general formula for calculating ENPV indicator for the mine can have the following form (Florio et al., 2001; European Commission, 2008):

$$
E N P V=\sum_{t=0}^{t=n} a_{t} \cdot S_{t}^{E}=\frac{S_{0}^{E}}{(1+r)^{0}}+\frac{S_{1}^{E}}{(1+r)^{1}}+\ldots+\frac{S_{n}^{E}}{(1+r)^{n}}
$$

where:

$S^{E}$ - balance of economic flows of costs and benefits generated by the mine in each year of the selected period,

$n$ - reference period in years (the period covered by the analysis),

$a$ - economic discount factor equal to: $a_{t}=\frac{1}{(1+r)^{t}}$,

$r$ - economic discount rate.

Additionally, a modified methodology of Dynamic Generation Cost (DGC) was applied in order to relate the results of CBA to the size of mining output. Dynamic Generation Cost is equal to the price that allows for discounted income equal discounted costs. DGC shows the technical cost of obtaining a unit of product (unit quantities of extracted coal) (Rączka, 2002). When the cost in the DGC index calculation is substituted with the balance of economic flows of the costs and benefits generated by the mine, the calculation results in an indicator of Economic Dynamic Generation Cost EDGC. This indicator provides information about economic benefits (if ENPV> 0) or costs (if ENPV < 0) of mining operation per unit of coal sold. As a result, the general formula for the EDGC index is as follows:

$$
E D G C=\frac{\sum_{t=0}^{t=n} \frac{S_{t}^{E}}{(1+r)^{t}}}{\sum_{t=0}^{t=n} \frac{W_{t}}{(1+r)^{t}}}
$$

where:

$W_{t}$ - total productivity expressed by commercial coal mining in a year $t,[\mathrm{Mg}]$,

$S^{E}$ - balance of economic flows of costs and benefits generated by the mine in a year $t$ $[\mathrm{PLN}]$,

$r$ - economic discount rate [\%],

$n$ - reference period in years. 
The transformation of the market prices into the accounting prices involved a standard conversion factor calculated by the following formula (Florio et al., 2001; European Commission, 2008):

$$
S W P=(M+X) /\left(M+T_{m}\right)+\left(X-T_{x}\right)
$$

where:

$$
\begin{gathered}
M-\text { total imports [PLN], } \\
X-\text { total exports [PLN], } \\
T_{m}-\text { import taxes [PLN], } \\
T_{x}-\text { export taxes [PLN]. }
\end{gathered}
$$

CBA included these social costs and benefits, and ecological losses, which in the case of the analysed mines actually occurred and which were possible to quantify and valuate in monetary units. These include the following items:

- external social benefits from the cooperation,

- benefits from direct tax income transferred to the budgets of municipalities/counties,

- benefits from employment - created (maintained) jobs,

- costs of accidents at work - minor,

- costs of occupational diseases - pneumoconiosis,

- losses in the aquatic environment,

- losses of hard coal, not connected with the exploitation,

- losses resulting from the degradation of soil,

- losses on the surface.

The formula applied for valuation of the external social benefits of cooperation with other entities is (own elaboration on the basis of Bartik 2011; Fujiwara 2010; Rzepecki 2005):

$$
K O_{S K O P}=(L M P \cdot(P W P-Z B))+((L M P \cdot S Z B)+(L M P \cdot((P D \cdot P W P)-P B)))
$$

where:

$L M P$ - estimated number of workplaces in cooperating companies [full-time employment],

$P W P$ - average salary in the industry [PLN],

$Z B$ - amount of unemployment benefit (100\% share) [PLN],

$S Z B$ - contributions of unemployment benefits rates (100\% share) [PLN],

$P B$ - taxes for unemployment benefits (100\% share) [PLN],

$P D$ - level index of income tax from natural persons [\%].

The formula for the valuation of external social benefits tax income paid to the budget of the municipality/county is as follows (own study based on the European Commission, 2008; Kasztelewicz and Zajączkowski 2010):

$$
K O_{S W P}=\left(P O E \cdot\left(O E \cdot W_{K}\right)\right)
$$

where:

$P O E$ - coefficient of the amount of maintenance fees paid to the municipalities/counties $[\%]$,

$O E$ - rate of exploitation fee for hard coal [PLN/Mg],

$W_{K}$ - gross hard coal production, in total [Mg]. 
The value of employees' salaries adjusted by shadow payroll was adopted as the value of external social benefits resulting from maintained jobs. The coefficient was calculated from the following formula (European Commission, 2008):

$$
W P D=(1-u) \cdot(1-t)
$$

where:

$u$ - unemployment rate in the region [\%],

$t$ - rate of contributions for social insurance and applicable taxes [\%].

The formula for the valuation of the social costs of an external minor accident at work has the following form (own elaboration on the basis of Rzepecki 2005):

$$
K_{S W L}=L_{W L} \cdot\left(I S K_{L}+K_{N F Z L}\right)
$$

where:

$L_{W L}$ - number of minor accidents [number of people],

$I S K_{L}$ - other components included in the cost of minor accidents for an injured employee and the family (among others: costs of treatment, purchase of medicine, transportation, purchase of necessities) [PLN],

$K_{N F Z L}$ - minor accident costs covered by the National Health Fund (NFZ) [PLN].

The formula for the valuation of external social costs of occupational disease - pneumoconiosis, of former miners is as follows (own elaboration on the basis of Rzepecki 2006):

$$
\begin{aligned}
& K_{S C H Z P N E}=\left(L_{C H Z P N E} \cdot\left(P U N Z_{C H Z P} \cdot S J O_{C H Z}\right)\right)+ \\
& +\left(\left(L_{C H Z P N E} \cdot W P S R_{P}\right) \cdot(W S ́ Z \cdot P R N P \cdot P O P E)\right)
\end{aligned}
$$

where:

$L_{C H Z P N E}$ - pneumoconiosis incidence rate (former employees) [number of people], $P U N Z_{C H Z P}$ - average reported percentage of impairment of health in case of occupational disease - pneumoconiosis [\%],

$\mathrm{SJO}_{\mathrm{CHZ}}$ - Social Insurance Institution (ZUS) rate of a single compensation for an accident at work and occupational diseases for $1 \%$ of impairment of health [PLN],

$W P S R_{P}$ - index of average participation of annuities granted in the case of found occupational disease - pneumoconiosis [\%],

$W S ́ Z$ - treatment benefits index,

$P R N P$ - average amount of pension for incapacity for work (miners) [PLN],

$P O P E$ - average period of granted retirement pensions (miners) [number of months].

Ecological losses caused in the aquatic environment were calculated according to the following formula (own study based on Mokrzycki et al., 1992; Famielec, 1999; Piontek (eds.), 1989):

$$
S_{w}=0,96 \cdot P_{w} \cdot\left(Z_{z s}+Z_{k u}\right)+0,00166 \cdot P_{r} \cdot P_{T G} \cdot U_{u r} \cdot L_{m c}
$$

where:

$P_{w}-$ industrial water consumption from surface and underground $\left[\mathrm{m}^{3}\right]$,

$Z_{z s}$ - reduction in capacity of water for self-cleaning $\left[\mathrm{PLN} / \mathrm{m}^{3}\right]$, 
$Z_{k u}$ - increased costs of treatment of excessively polluted water $\left[\mathrm{PLN} / \mathrm{m}^{3}\right]$,

$P_{r}-$ global agricultural production of a region [PLN/ha],

$P_{T G}$ - mining area [ha],

$U_{u r}$ — share of the agricultural area (agricultural land) in total area of the region [\%],

$L_{m c}$ - number of months included in the analysis.

Coal losses not connected to the exploitation werre calculated by the formula (own study based on Mokrzycki et al., 1992; Famielec, 1999; Piontek (eds.), 1989):

$$
S_{e}=0,207 \cdot W_{c} \cdot \frac{P_{s w}}{S_{w}}
$$

where:

$W_{c}$ - gross coal extraction $[\mathrm{Mg}]$,

$P_{s w}$ — income from sale of hard coal [PLN],

$S_{w}$ - sale of hard coal $[\mathrm{Mg}]$.

Losses resulting from the degradation of soil were calculated according to the formula (own study based on Mokrzycki et al., 1992; Famielec, 1999; Piontek (eds.), 1989):

$$
S_{g}=0,0208 \cdot D_{k l} \cdot P_{T G} \cdot U_{u r} \cdot L_{m c}
$$

where:

$D_{k l}$ - additional costs of liquidation of negative effects of chemicals [PLN/ha],

$P_{T G}$ - mining area [ha],

$U_{u r}$ — share of agricultural land in total area of the region [\%],

$L_{m c}$ - number of months included in the analysis.

Losses on the surface were calculated using the following formula (own study based on Mokrzycki et al., 1992; Gawrońska, 2000; Piontek (eds.), 1989):

$$
S_{p}=W_{t r l} \cdot P_{t r l}+R+K_{l s g}+0,083 \cdot\left(K_{d} \cdot P_{T G} \cdot U_{l} \cdot V_{d} \cdot B_{d} \cdot L_{m c}\right)
$$

where:

$W_{t r l}$ - losses due to agricultural land and forest land handed over for other purposes [PLN/ha],

$P_{t r l}$ — agricultural land and forest land exploited for non-agricultural, non-forest purposes [ha],

$R$ - reclamation costs $[\mathrm{PLN}]$,

$K_{l s g}$ - liquidation costs of mining damage (including funded by grant budget) [PLN],

$K_{d}-$ cost of timber $\left[\mathrm{PLN} / \mathrm{m}^{3}\right]$,

$P_{T G}$ - mining area [ha],

$U_{l}$ - the share of forest land area in Poland [\%],

$V_{d}$ - annual growth of wood with a layer of shrubs $\left[\mathrm{m}^{3} / \mathrm{ha}^{*}\right.$ year],

$B_{d}$ - rate of decline in growth of timber,

$L_{m c}$ - number of months included in the analysis. 


\section{List of data used in Cost Benefit Analysis of the mine}

Calculations based on averaged data acquired from two selected coal mines located in the Upper Silesian Coal Basin were carried out in order to verify the application of the methodology for CBA adopted for mine economic assessment. Conversion factors, constants and statistical values were assumed or converted on the basis of data included in the literature to the price level of 2013. Due to the lack of availability of data from mines with a long (long-term) time frame, the assessment included data from the first half of 2013. These include in particular the following areas:

- production and sale level of coal,

- current production costs (coal mining) divided into particular cost by type,

- accidents and occupational diseases incidence rate,

- emission of pollutants into the environment,

- range and scale of harmful effects of the mine on land.

Valuation of social and environmental external costs and benefits of coal mines activity included the following internal data from mining companies, fixed data and external data from public statistics. The data is presented in Table 1 .

TABLE 1

List of data used in Cost Benefit Analysis of the mine

\begin{tabular}{|c|c|c|}
\hline Data type & Unit & Data source \\
\hline 1 & 2 & 3 \\
\hline \multicolumn{3}{|c|}{ Valuation of external social costs and benefits of mining activity } \\
\hline \multicolumn{3}{|c|}{ 1. Benefits of cooperation with other entities } \\
\hline cost of materials & PLN & \multirow{2}{*}{ Operating data } \\
\hline cost of third-party services & PLN & \\
\hline share index of labour costs (production) & $\%$ & $\begin{array}{l}\text { Constant based on NBP } \\
\text { calculations }\end{array}$ \\
\hline share index of labour costs (service) & $\%$ & $\begin{array}{l}\text { Constant based on NBP } \\
\text { calculations }\end{array}$ \\
\hline average salary in the industry & PLN & Statistical Office in Katowice \\
\hline amount of unemployment benefit (100\% share) & PLN & Ministry of Labour \\
\hline $\begin{array}{l}\text { contributions of unemployment benefits rates }(100 \% \\
\text { share) }\end{array}$ & PLN & Ministry of Labour \\
\hline taxes for unemployment benefits ( $100 \%$ share $)$ & PLN & Ministry of Labour \\
\hline income tax for natural persons & $\%$ & $\begin{array}{l}\text { Constant based on regulations } \\
\text { of the Ministry of Finance }\end{array}$ \\
\hline \multicolumn{3}{|c|}{ 2. Benefits from tax income transferred to the budgets of municipalities/counties } \\
\hline gross hard coal production & $\mathrm{Mg}$ & Operating data \\
\hline $\begin{array}{l}\text { POE - coefficient of the amount of maintenance } \\
\text { fees paid to the municipalities/counties, based on } \\
\text { applicable regulations }\end{array}$ & $\%$ & $\begin{array}{l}\text { Rate established by the Prime } \\
\text { Minister }\end{array}$ \\
\hline rate of exploitation fee for hard coal & $\mathrm{PLN} / \mathrm{Mg}$ & $\begin{array}{l}\text { Applicable regulation of the } \\
\text { Council of Ministers }\end{array}$ \\
\hline
\end{tabular}




\begin{tabular}{|c|c|c|}
\hline 1 & 2 & 3 \\
\hline \multicolumn{3}{|l|}{ 3. Employment - created (maintained) jobs } \\
\hline unemployment rate in the region & $\%$ & Statistical Office in Katowice \\
\hline $\begin{array}{l}\text { rate of social security contributions and applicable } \\
\text { taxes }\end{array}$ & $\%$ & $\begin{array}{l}\text { Constant based on regulations } \\
\text { of the Ministry of Finance }\end{array}$ \\
\hline \multicolumn{3}{|l|}{ 4. Accidents at work } \\
\hline minor accidents - mine employees & $\begin{array}{l}\text { number of } \\
\text { people }\end{array}$ & \multirow{3}{*}{ Operating data } \\
\hline $\begin{array}{l}\text { salaries (salaries, social insurance, employee benefits) } \\
\text { (average amount per month) }\end{array}$ & PLN & \\
\hline registered employees on average: total & $\begin{array}{l}\text { number of } \\
\text { people }\end{array}$ & \\
\hline $\begin{array}{l}\text { other components included in the cost for major } \\
\text { accidents for an injured employee and the family } \\
\text { (among others: costs of treatment, purchase of } \\
\text { medicine, transportation, purchase of necessities) }\end{array}$ & PLN & $\begin{array}{l}\text { constant based on studies of } \\
\text { CIOP - PIB }\end{array}$ \\
\hline minor accident costs covered by $\mathrm{NFZ}^{2}$ & PLN & $\begin{array}{l}\text { constant based on studies of } \\
\text { CIOP - PIB }\end{array}$ \\
\hline \multicolumn{3}{|l|}{ 5. occupational diseases } \\
\hline $\begin{array}{l}\text { pneumoconiosis incidence rate (employees and } \\
\text { former employees) }\end{array}$ & $\begin{array}{l}\text { number of } \\
\text { people }\end{array}$ & \multirow{3}{*}{ Operating data } \\
\hline $\begin{array}{l}\text { salaries (salaries, social insurance, employee benefits) } \\
\text { (average amount per month) }\end{array}$ & PLN & \\
\hline registered employees on average & $\begin{array}{l}\text { number of } \\
\text { people }\end{array}$ & \\
\hline $\begin{array}{l}\text { average reported percentage of impairment of health } \\
\text { in case of occupational disease - pneumoconiosis }\end{array}$ & $\%$ & ZUS \\
\hline $\begin{array}{l}\text { ZUS rate of a single compensation for an accident at } \\
\text { work and occupational diseases for } 1 \% \text { of impairment } \\
\text { of health }\end{array}$ & PLN & ZUS \\
\hline $\begin{array}{l}\text { index of average participation of annuities granted } \\
\text { in the case of found occupational disease - } \\
\text { pneumoconiosis }\end{array}$ & $\%$ & ZUS \\
\hline $\begin{array}{l}\text { minimum period of payment of sickness benefits } \\
\text { by ZUS before obtaining disability benefits for an } \\
\text { occupational disease }\end{array}$ & months & ZUS \\
\hline $\begin{array}{l}\text { average period of pension due to occupational } \\
\text { diseases prior treatment benefits }\end{array}$ & months & ZUS \\
\hline treatment benefits index & - & ZUS \\
\hline $\begin{array}{l}\text { average amount of pension for incapacity for work } \\
\text { (miners) }\end{array}$ & PLN & ZUS \\
\hline $\begin{array}{l}\text { average period of granted retirement pensions } \\
\text { (miners) }\end{array}$ & months & ZUS \\
\hline \multicolumn{3}{|c|}{ Valuation of the external environmental costs and benefits of mining activity } \\
\hline \multicolumn{3}{|c|}{ 1. Losses in the aquatic environment } \\
\hline $\begin{array}{l}\text { industrial water consumption from surface and } \\
\text { underground intakes }\end{array}$ & $\mathrm{m}^{3}$ & \multirow[t]{2}{*}{ Operating data } \\
\hline mining area & ha & \\
\hline
\end{tabular}




\begin{tabular}{|c|c|c|}
\hline 1 & 2 & 3 \\
\hline reduction index in capacity of water for self-cleaning & $\mathrm{PLN} / \mathrm{m}^{3}$ & $\begin{array}{l}\text { Constant based on scientific } \\
\text { publications (Famielec, 1999) }\end{array}$ \\
\hline $\begin{array}{l}\text { index of increased costs of treatment of excessively } \\
\text { polluted water treatment }\end{array}$ & $\mathrm{PLN} / \mathrm{m}^{3}$ & $\begin{array}{l}\text { Constant based on scientific } \\
\text { publications (Famielec, 1999) }\end{array}$ \\
\hline loss rate related to the shortage (excess) of water & $\%$ & $\begin{array}{l}\text { Constant based on scientific } \\
\text { publications (Mokrzycki, 1992) }\end{array}$ \\
\hline global agricultural production of a region & $\mathrm{PLN} / \mathrm{ha}$ & GUS \\
\hline share of agricultural land in total area of the region & $\%$ & GUS \\
\hline \multicolumn{3}{|l|}{ 2. Losses of hard coal, not connected with the exploitation } \\
\hline gross hard coal extraction & $\mathrm{Mg}$ & \multirow{3}{*}{ Operating data } \\
\hline income from sale of hard coal & PLN & \\
\hline sale of hard coal & $\mathrm{Mg}$ & \\
\hline loss index not connected with the exploitation & $\%$ & $\begin{array}{l}\text { Constant based on scientific } \\
\text { publications (Mokrzycki, 1992) }\end{array}$ \\
\hline \multicolumn{3}{|l|}{ 3. Losses resulting from the degradation of soils } \\
\hline mining area & ha & Operating data \\
\hline $\begin{array}{l}\text { additional costs index of liquidation of negative } \\
\text { effects of chemicals }\end{array}$ & PLN/ha & $\begin{array}{l}\text { Constant based on scientific } \\
\text { publications (Famielec, 1999) }\end{array}$ \\
\hline share of agricultural land in total area of the region & $\%$ & GUS \\
\hline \multicolumn{3}{|l|}{ 4. Losses on the surface } \\
\hline $\begin{array}{l}\text { liquidation costs of mining damage (including funded } \\
\text { by grant budget) }\end{array}$ & PLN & \multirow[t]{2}{*}{ Operating data } \\
\hline mining area & ha & \\
\hline $\begin{array}{l}\text { loss index due to agricultural land and forest land } \\
\text { handed over for other purposes }\end{array}$ & PLN/ha & $\begin{array}{l}\text { Constant based on scientific } \\
\text { publications (Famielec, 1999) }\end{array}$ \\
\hline cost of timber, $1 \mathrm{~m}^{3}$ & $\mathrm{PLN} / \mathrm{m}^{3}$ & $\begin{array}{l}\text { Constant based on scientific } \\
\text { publications (Mokrzycki, 1992) }\end{array}$ \\
\hline the share of forest land area in Poland & $\%$ & GUS \\
\hline annual growth of wood with a layer of shrubs & $\mathrm{m}^{3} /$ ha*year & $\begin{array}{l}\text { Constant based on scientific } \\
\text { publications (Mokrzycki, 1992) }\end{array}$ \\
\hline rate of decline in growth of timber, & - & $\begin{array}{l}\text { Constant based on scientific } \\
\text { publications (Mokrzycki, 1992) }\end{array}$ \\
\hline \multicolumn{3}{|c|}{ Calculation of the financial aspects of coal mines } \\
\hline sales of hard coal & $\mathrm{Mg}$ & \multirow{3}{*}{$\begin{array}{l}\text { Operating and financial data } \\
\text { from mines }\end{array}$} \\
\hline current production costs & PLN & \\
\hline average sales price of coal & $\mathrm{PLN} / \mathrm{Mg}$ & \\
\hline standard conversion factor & - & $\begin{array}{l}\text { The value calculated from the } \\
\text { formula ( } 3 \text { ) is equal to } 1\end{array}$ \\
\hline
\end{tabular}

where:

NBP - National Bank of Poland

CIOP-PIB - Central Institute for Labour Protection - National Research Institute

NFZ - National Health Fund

ZUS - Social Insurance Institution

GUS - Central Statistical Office 


\section{The results of the analysis and a discussion regarding results}

The performed analysis includes operating data from the first half of 2013, due to the fact that data from a longer period was not available. The research is focused primarily on current mining operations and the coal production process. The purpose of the analysis is not comprehensive economic assessment of a particular coal mine, but to verify the adopted calculation methodology; whereas, the proposed methodology enables to carry out the analysis using data from longer periods, taking into account the economic discount rate. The results of calculations of income and benefits and costs are summarized in Table 1. No major and fatal accidents at work or occupational diseases hearing damage and vibration syndrome occurred during the analysed period. Therefore these positions of the social are indicated as 0 . Flows were calculated and expressed in monetary units estimated for the analysed period, and were applied as the basis for calculating ENPV and EDGC indicators according to formulas (1) and (2). The results of calculations are presented in Table 2 .

TABLE 2

The results of Cost Benefit Analysis (CBA) conducted on the basis of averaged data of the selected mines in Poland

\begin{tabular}{|c|c|c|}
\hline Item & Unit & Values of analysed period \\
\hline \multicolumn{3}{|l|}{ Financial income and social benefits } \\
\hline Total revised income of the mine & thous. PLN & $492,984.5$ \\
\hline Revised benefits from employment & thous. PLN & $78,014.4$ \\
\hline External social benefits from the cooperation & thous. PLN & $62,731.4$ \\
\hline $\begin{array}{l}\text { Benefits from tax income paid to the budgets of } \\
\text { municipalities/counties }\end{array}$ & thous. PLN & $2,879.0$ \\
\hline TOTAL income and benefits & thous. PLN & $636,609.3$ \\
\hline \multicolumn{3}{|l|}{ Financial, environmental and social costs } \\
\hline Total revised costs of current production & thous. PLN & $450,291.6$ \\
\hline Costs of accidents at work - minor & thous. PLN & 170.6 \\
\hline Costs of accidents at work - major & thous. PLN & 0.0 \\
\hline Costs of accidents at work - fatal & thous. PLN & 0.0 \\
\hline Costs of occupational diseases - pneumoconiosis & thous. PLN & 478.3 \\
\hline Costs of occupational diseases - hearing damage & thous. PLN & 0.0 \\
\hline Costs of occupational diseases - vibration syndrome & thous. PLN & 0.0 \\
\hline Losses in the aquatic environment & thous. PLN & 452.8 \\
\hline Losses of hard coal, not connected with the exploitation & thous. PLN & $101,138.8$ \\
\hline Losses resulting from the degradation of soil & thous. PLN & 86.4 \\
\hline Losses on the surface & thous. PLN & $5,002.4$ \\
\hline TOTAL exploitation, environmental and social costs & thous. PLN & $557,620.9$ \\
\hline Flows expressed in monetary units & thous. PLN & $78,988.4$ \\
\hline Hard coal production & $\mathrm{Mg}$ & $1,590,273$ \\
\hline Discounted hard coal production & $\mathrm{Mg}$ & $1,590,273$ \\
\hline Discounted cash flows & thous. PLN & $78,988.4$ \\
\hline Discounted ENPV for mining activity & thous. PLN & $78,988.4$ \\
\hline EDGC coefficient for coal production & $\mathrm{PLN} / \mathrm{Mg}$ & 49.7 \\
\hline
\end{tabular}

Source: own calculations 
Obtained results allow to conclude that the methodology adopted for CBA is possible to be used in practice in order to assess the economic efficiency of mines and for the coal production process in Poland. Data necessary to carry out an analysis can be acquired both, from the same mines, as well as from public sources and official statistics. The results presented in Table 2 indicate that the economic assessment of the mine is significantly impacted by social costs and ecological damage caused by mining operations. These two aspect constitute approx. $19 \%$ of total costs of all categories of the analysed case. On the contrary, a significant share of the current production cost directly impacts social benefits, increasing the well-being of local residents, as well as contributes to improved situation in the region. The subject calculation estimated that approx. $23 \%$ of the cost of mining operation involves social benefits in terms of the local and regional population, as well as the general public. A positive value of ENPV indicates that the subject mines generated in the first half of 2013 more financial, social and environmental benefits than costs. Obtained index value equal to 49.7 EDGC PLN/Mg during the selected period was much lower than that an average unit cost of coal production, which amounted to approx. 290 PLN/Mg for the selected period.

\section{Conclusion}

Proposed methodology for Cost Benefit Analysis of coal mines can bring tangible benefits in their comprehensive assessment in terms of economic efficiency. This methodology allows to conduct assessments of mines in broad terms, including the assessment of most significant environmental aspects (particularly the water and air pollution or land degradation), the social aspects of local and national relevance (direct employment, cooperation with other employers, the cost of accidents at work and occupational diseases). Therefore, the results of CBA, in addition to financial aspects which are essential for the owner of the mine, recognize the effects of activities related to coal mining in terms of environmental and social aspects. Adopted methodology for CBA was reviewed using averaged data from two selected coal mines located in the Upper Silesian Coal Basin. The results indicate that it is possible to apply the method in order to assess the economic efficiency of coal mines in Poland. It is particularly determined by the availability necessary to perform analysis of data and the extent of included social and environmental aspects. Proposed methodology enables to conduct the analysis using data from long-standing periods, consequently, the analysis should include such periods taking into account the nature of the operation of coal mines in Poland. The results of analysis based on data from long periods can be a basis od conclusions in the field of economic assessment of mines. In addition, the methodology assumes the possibility of further expansion of evaluation scope and takes into account externalities, such as effects of branding of business activities, rehabilitation of post-mining areas, where proper valuation requires further research, or need to increase the availability of data.

The paper was prepared within the framework of the project titled "Developing an expert system to assess environmental, economic and social efficiency of coal mines in Poland" financed by the National Centre for Research and Development within the framework of the Applied Research Program. 


\section{References}

Bartik T.J., 2011. Including Jobs in Benefit-Cost Analysis. Upjohn Institute Working Paper 11-178. Kalamazoo. MI: W. E. Upjohn Institute for Employment Research.

Berman R., 2009. Wycena wartości złóż kopalin. Wybrane metody wyceny. Prace Naukowe Instytutu Górnictwa Politechniki Wrocławskiej, Nr 35.

Burchart-Korol D., Krawczyk P., Śliwińska A., Czaplicka-Kolarz K., 2013. Ocena ekoefektywności systemu produkcyjnego technologii naziemnego zgazowania węgla. Przemysł Chemiczny, 2013, 92, 3, 384.

Burchart-Korol D., Krawczyk P., Czaplicka-Kolarz K., Turek M., Borkowski W., 2014. Development of sustainability assessment method of coal mine. Journal of Sustainable Mining, 13(4), 5-11. doi: 10.7424/jsm140402.

Burzyńska D., Fila J., 2007. Finansowanie inwestycji ekologicznych w przedsiębiorstwie. Wydawnictwo Difin, Warszawa, s. 65-68.

Cała M. (red.), 2013. Mining Waste Management in the Baltic Sea Region. Min-Novation project. Wydawnictwa AGH, Kraków.

Czaplicka-Kolarz K., Burchart-Korol D., Turek M., Borkowski W., 2015. Model of eco-efficiency assessment of mining production processes. Arch. Min. Sci., Vol. 60, No 2, p. 497-506.

Czaplicka-Kolarz K., 2014. Zidentyfikowanie, agregacja i weryfikacja istotnych procesów jednostkowych kopalń węgla kamiennego oraz zwiazanych z nimi danych wejściowych $i$ wyjściowych na potrzeby budowy systemu ekspertowego. Załącznik 2. Sprawozdanie merytoryczne w ramach projektu „Opracowanie systemu ekspertowego do oceny efektywności środowiskowej, ekonomicznej i społecznej kopalń węgla kamiennego w Polsce”.

Czaplicka-Kolarz K., Ściążko M. (red.) 2004. Model ekologicznego i ekonomicznego prognozowania wydobycia i użytkowania czystego węgla - Ekoefektywność technologii czystego spalania węgla. GIG, Katowice.

Czaplicka-Kolarz K. (red.), 2002. Zastosowanie oceny cyklu życia (LCA) w ekobilansie kopalni. Wydawnictwo GIG, Katowice.

Drobniak A., 2002. Zastosowanie analizy kosztów i korzyści w ocenie projektów publicznych. Wydawnictwo Akademii Ekonomicznej w Katowicach, Katowice.

Dubiński J., Turek M., 2014. Chances and Threats of Hard Coal Mining Development in Poland-the Results of Experts Research. Arch. Min. Sci., Vol. 59, No 2, p. 395-411.

Dubiński J., 2013. Sustainable development of mining mineral resources. Journal of Sustainable Mining, Vol. 12, No. 1, p. 1-6.

Famielec J., 1999. Straty i korzyści ekologiczne w gospodarce narodowej. PWN, Warszawa-Kraków.

Fiedor B. (red.), 2002. Podstawy ekonomii środowiska i zasobów naturalnych. Wydawnictwo C.H. Beck, Warszawa.

Florio M. i in., 2001. Analiza kosztów i korzyści projektów inwestycyjnych: Przewodnik (Fundusz Strukturalny - EFRR, Fundusz Spójności i ISPA). Jednostka ds. Ewaluacji, Dyrekcja Generalna - Polityka Regionalna, Komisja Europejska.

Fujiwara D., 2010. Social Cost-Benefit Analysis framework methodologies for estimating and incorporating the wider social and economic impacts of work in Cost-Benefit Analysis for employment programmes. The Department for Work and Pension, Londyn.

Gillespie R., Krat M.E., 2010. Valuing the Non-Market Impacts of Underground Coal Mining. The University of western Australia, December 2010.

Gillespie Economics, 2011. South East Open Cut Project and Ashton Coal Project Modification. Appendix 18. Benefit Cost Analysis.

Henzej H., Jędrzejczyk I., Lorek E., 2000. Metodologia zintegrowanej oceny inwestycji ochronnych na przykładzie zbiornika wodnego Racibórz. [W:] Ekonomika inwestowania. Aspekty finansowe i ekologiczne. Wydawnictwo Akademii Ekonomicznej w Katowicach, Katowice.

Janik A., 2012. Wielokryterialna metoda wyceny wartości terenów zdegradowanych. Zeszyty Naukowe Politechniki Śląskiej, Organizacja i Zarządzanie, Katowice, z. 62, s. 57-79.

Kasztelewicz Z., Zajączkowski M., 2010. Wpływ działalności górnictwa węgla brunatnego na sektor publiczny. Górnictwo i Geoinżynieria 4/2010, Wydawnictwo AGH, Kraków. 
Kawala J. i in., 2002. Realizacja projektów infrastrukturalnych w gminach wiejskich. LEMTECH Konsulting Sp. z o.o. Kraków.

Komisja Europejska Dyrekcja Generalna ds. Polityki Regionalnej, 2008. Przewodnik do analizy kosztów i korzyści projektów inwestycyjnych.

Komunikat Prezesa Głównego Urzędu Statystycznego w sprawie średniej ceny drewna, obliczonej według średniej ceny drewna uzyskanej przez nadleśnictwa (M. P. 2014 poz.955)

Kudełko M., 2005. Model decyzyjny przedsiębiorstwa pozyskiwania surowców skalnych. Czasopismo Stowarzyszenia Ekonomistów Środowiska i Zasobów Naturalnych „Ekonomia i Środowisko“, nr 1(27), Białystok.

Kudełko M., 2013a. Metodyka i założenia wyceny kosztów zewnętrznych powodowanych przez planowane elektrownie wykorzystujące złoża węgla brunatnego Legnica i Gubin. Polityka Energetyczna, t. 16, zeszyt 1.

Kudełko M., 2013b. Szacunek kosztów zewnętrznych powodowanych przez planowane elektrownie wykorzystujące złoża węgla brunatnego Legnica i Gubin oraz krajowy sektor energetyczny. Polityka Energetyczna, t. 16, zeszyt 2.

Kulczycka J., Koneczny K., Kowalski Z., 2003. Cost-benefit analysis for the assessment of environmental aspects of mining industry. Gospodarka Surowcami Mineralnymi, Tom 19, Zeszyt 4.

Kulczycka J., 2011. Ekoefektywność projektów inwestycyjnych z wykorzystaniem koncepcji cyklu życia produktu. Studia, Rozprawy, Monografie 169, Wydawnictwo IGSMiE PAN, Kraków 2011, ISBN 978-83-60195-29-1, s. 252.

Kulczycka J., Berman R., Faworyta W., 2012a. Korzyści makro- i mikroekonomiczne z wykorzystaniem kopalin towarzyszacych $i$ odpadów wydobywczych $w$ górnictwie węgla brunatnego. Zeszyty Naukowe Instytutu Gospodarki Surowcami Mineralnymi i Energią PAN, nr 83.

Kulczycka J., Berman R., Cholewa M., 2012b. Analiza kosztów i korzyści zagospodarowania odpadów górnictwa węgla kamiennego. Proceedings of Conference at the University of Economics, Katowice 17-19.IX.2012.

Ligus M., 2010. Efektywność inwestycji w odnawialne źródła energii. Analiza kosztów i korzyści. Wydawnictwo CeDeWu Sp. z o.o., Warszawa.

Martyka J., Nowak K., Tausz K., 2001. Uciążliwości związane z bliskim sąsiedztwem kopalń w opinii społecznej. Człowiek i środowisko wobec procesu restrukturyzacji górnictwa węgla kamiennego. Biblioteka Szkoły Eksploatacji Podziemnej, Katowice, Seria z Lampką Górniczą, t. 6, s. 63-74.

Mokrzycki E. i in., 1992. Skutki oddziaływania zanieczyszczeń na środowisko przyrodnicze i metody szacowania strat. Polska Akademia Nauk-Kraków, Wydawnictwo CPPGCMiE PAN, Kraków.

Piontek F. (red.), 1989. Straty spowodowane degradacją powierzchni ziemi w Województwie Katowickim. Zakład Narodowy im. Ossolińskich, Wrocław.

Piontek F., 1992. Społeczno-Ekonomiczne koszty i uwarunkowania wydobycia węgla w Województwie Katowickim. Akademia Ekonomiczna, Urząd Wojewódzki w Katowicach, Katowice.

Rączka J., 2002. Analiza efektywności kosztowej w oparciu o wskaźnik dynamicznego kosztu jednostkowego. Materiały szkoleniowe opracowane w ramach TRANSFORM ADVICE PROGRAMME - Investment in Environmental Infrastructure in Poland.

Rydlewska-Liszkowska I., 2006. Koszty chorób zawodowych $i$ wypadków przy pracy w Polsce. Medycyna Pracy, 4/2006, s. 319.

Rzepecki J., 2005. Spoleczne koszty wypadków przy pracy w Polsce. Bezpieczeństwo pracy, 7-8/2005, s. 36.

Surdej A., 2008. Metoda analizy kosztów i korzyści: imperatyw efektywności w politykach publicznych w Środowisko $i$ warsztat ewaluacji. PARP, s. 109-126, Warszawa.

Tausz K. (red.), 2009. Losy rodzin górników, którzy zginęli w wypadku przy pracy. Praca zbiorowa, Wyd.: Główny Instytut Górnictwa, Katowice.

Turek M., 2013. System zarządzania kosztami w kopalni węgla kamiennego w cyklu istnienia wyrobiska wybierkowego. Wydawnictwo Difin S.A., Warszawa.

Urząd Statystyczny w Katowicach, 2013. Biuletyn Statystyczny Województwa Śląskiego. III Kwartał 2013, s. 33, Katowice.

Wyższy Urząd Górniczy, 2014. Ocena stanu bezpieczeństwa pracy, ratownictwa górniczego oraz bezpieczeństwa powszechnego w związu z działalnościa górniczo-geologiczna w 2013 roku (na tle porównawczym od 2008 roku). Katowice. 
Zakład Ubezpieczeń Społecznych, Departament Statystyki i Prognoz Aktuarialnych, 2013. Informacja o świadczeniach pieniężnych z Funduszu Ubezpieczeń Społecznych oraz o niektórych świadczeniach z zabezpieczenia społecznego. II Kwartał/Okres I-VI 2013 r., s. 21, Warszawa.

Zakład Ubezpieczeń Społecznych, Departament Statystyki, 2007. Analiza wyników badania okresów pobierania emerytur i rent. s. 44-49, Warszawa.

Zakład Ubezpieczeń Społecznych, Departament Statystyki, 2009. Emerytury i renty górnicze w 2008 roku. s. 7-8, Warszawa.

Zakład Ubezpieczeń Społecznych, 2010. Prewencja wypadkowa w Zakładzie Ubezpieczeń Społecznych. s. 14-15, Warszawa.

Zakład Ubezpieczeń Społecznych, 2012. Rocznik Statystyczny Ubezpieczeń Społecznych 2009-2011. s. 58, Warszawa.

Zakład Ubezpieczeń Społecznych, Departament Statystyki i Prognoz Aktuarialnych, 2013. Orzeczenia ustalajace procentowy uszczerbek na zdrowiu wydane w 2012 roku. s. 39, Warszawa. 